\title{
Analysis of Protein and Amino Acid Contents in Rice Flour by Near-infrared Spectroscopy
}

\author{
Mutsuo Iwomoto*, Tadanao SuzuKI*, Ngamchuen KongSEREE** \\ Jun Uozumi* and Osamu Inatsu*** \\ * National Food Research Institute, Ministry of :Agriculture, Forestry and \\ Fisheries, Kannondai, Yatabe-machi, Tuskuba-gun, Ibaraki-ken, 305 Japan \\ ** Rice Research Institute, Department of Agriculture, Bangkhen, \\ Bangkok 10900, Thailand \\ *** Hokkaido Central Agricultural Experiment Station, Naganuma, \\ Hokkaido, 069-13 Japan
}

\begin{abstract}
Near-infrared spectroscopic technique was studied for determination of protein and 4 kinds of amino acids in rice flour. As a result of detailed search for the NIR spectra of rice flour containing different protein level, the NIR was proved to have a sensitivity to rice protein as much as wheat one. It was possible to decrease a standard error of estimation for calibrations by using a derivative absorbance, but on the contrary derivative procedure possibly makes an increment in bias in case of prediction of "unknown" samples. It was verified that the NIR technique had a potential for a rapid method for analysis of protein and amino acids contents in rice flour.
\end{abstract}

Production of rice in the world reaches about 450 milion tons 1983, and the greater part of Asian countries consumes rice as a staple food. However, the rice is inferior to wheat in a point of contents of protein and amino acids, particularly lysine, therefore it is an important target of breeding programme to develop a new variety containing more protein and lysine.

In the course of the breeding programme, a great number of samples are necessarily analyzed at a time. Then there is a necessity to develop a more convenient method instead of time-consuming or skill-required chemical methods which are mainly used at present.

From this point of view, near-infrared diffuse reflectance spectroscopy (NIR), which has been applied to the breeding programme for several crops involving wheat and barley, is one of potential methods ${ }^{1)-3)}$. The greatest advantage of the NIR method is that in most cases no complicated sample preparations such as extraction, concentration, etc. are required before the analysis, but only a simple procedure such as milling, slicing, etc., if necessary.

This study was carried out in order to verify the possibility of NIR method for analysis of protein and 4 kinds of amino acids contents in rice flour.

\section{Materials and Methods}

\section{Materials}

All rice samples used for this study were cultivated at the Hokkaido Central Agricultural Experiment Station. Totally 40 samples from different varieties including 6 upland varieties were milled to an extent of $90 \%$ in degree of milling and ground with a cyclone grinder having a $0.5 \mathrm{~mm}$ screen.

The samples were divided into 2 groups. The first 20 samples were used for "calibration" samples, and another 20 samples were used as "prediction" samples in order to corroborate a performance of calibrations obtained. Values of range, mean and standard deviation of chemical compositions concerned in this study are shown in Table 1.

\section{NIR instrument}

The NIR measurement was made by using a Research Composition Analyzer 6350 (Pacific Scientific Co.). An analysis of the NIR data was carried out in the same way as described in previous papers ${ }^{4) 5}$. 
Table 1 Statistical data of compositions of protein and 4 kinds of amino acids in rice flours used

\begin{tabular}{|c|c|c|c|c|c|c|}
\hline \multirow{2}{*}{ Compositions } & \multicolumn{3}{|c|}{ Calibration samples } & \multicolumn{3}{|c|}{ Prediction samples } \\
\hline & Range(\%) & $\operatorname{Mean}(\%)$ & $\mathrm{SD}^{1 /}(\%)$ & Range(\%) & $\operatorname{Mean}(\%)$ & $\operatorname{SD}^{11}(\%)$ \\
\hline Asparatic acid & $0.56-1.02$ & 0.780 & 0.154 & $0.53-1.02$ & 0.742 & 0.147 \\
\hline Glycine & $0.29-0.48$ & 0.381 & 0.065 & $0.28-0.47$ & 0.361 & 0.060 \\
\hline Alanine & $0.34-0.62$ & 0.476 & 0.089 & $0.32-0.61$ & 0.450 & 0.084 \\
\hline Lysine & $0.22-0.37$ & 0.291 & 0.056 & $0.21-0.37$ & 0.274 & 0.054 \\
\hline Protein & $7.9-11.3$ & 8.62 & 1.65 & $6.2-11.2$ & 8. 10 & 1.48 \\
\hline
\end{tabular}

1) Standard deviation

Protein analysis

Protein content in about $2 \mathrm{~g}$ of each ground sample was analyzed by the KJELDAHL method ${ }^{6}$.

Amino acid analysis

Amino acid analysis was carried out on a Hitachi Amino Acid Analyzer (Model 835). $\mathrm{Al}_{1}$ procedures were performed in the same way as described in a previous paper ${ }^{7)}$.

\section{Results and Discussion}

NIR spectra of rice flour

NIR spectra of 2 varieties of which protein content are $11.2 \%$ and $6.7 \%$ respectively are shown in Fig. 1. The spectra show a typical characteristic that absorbance or $\log (1 / R)$ value increases with the scanning wavelength tested, and the value of a variety containing more protein is bigger than that of a variety containing less protein.

Fig. 2(A) demonstrates a difference spectrum

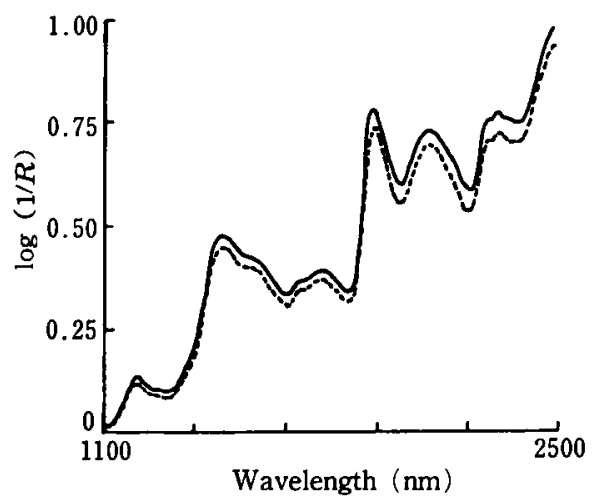

Fig. 1 Spectra of rice flour samples containing different protein level

$-11.2 \%, \cdots .6 .7 \%$

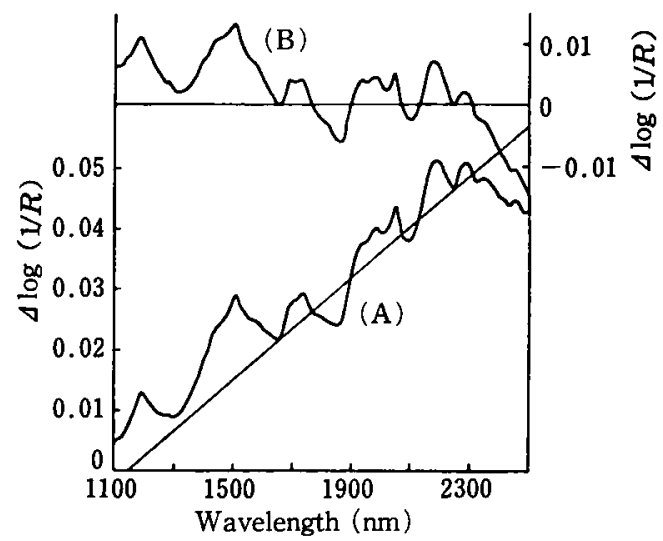

Fig. 2 Difference spectra between 2 samples of rice flour having difference of $4.5 \%$

(11. 2\%-6. 7\%) in protein content

(A) difference spectrum, $\Delta \log (1 / R)$

(B) normalized difference spectrum

$(A \log (1 / R))$ which was obtained by subtracting the $\log (1 / R)$ value of lower protein variety from that of higher one. The difference spectrum also shows the same pattern that the $\Delta \log$ $(1 / R)$ value increases with the scanning wavelength. About 10 peaks of maximal and minimal values in the spectrum are observed in the wavelength region from 1100 to $2500 \mathrm{~nm}$. On the other hand, Fig. 2 (B) shows a spectrum which was obtained by rormalizing the difference spectrum shown in Fig. 2(A). The normalizing was carried out by subtracting a baseline obtained as a straight line tangential to absorption minima at 1650 and $2250 \mathrm{~nm}$ from $\Delta \log (1 / R)$ values in Fig. $2(\mathrm{~A})$.

In the Fig. $2(\mathrm{~B})$, positive maxima are observed at many wavelengths such as 1510,1990 , 
2060 and $2180 \mathrm{~nm}$, while negative minima are observed at 2 wavelengths at 1860 and $2100 \mathrm{~nm}$.

A tendency that $\log (1 / R)$ value increases with protein content may be due to the reason that rice flour from harder grains necessarily produces a coaser particle size under the same milling condition, because texture of rice kernel increases in hardness with protein content and vice versa. A coaser particle creates more light penetration into the layer of flour, causing a prolongation in a pathway of light scattered, and consequently a bigger absorbance is produced. This tendency appears distinctly in a longer wavelength region which is closer to a region of fundamental vibration.

In the spectra shown in Fig. 1, it is not possible to find any special characteristics affected by the difference in protein content between the 2 samples except the difference in a background which was created by the difference in particle size between the samples, while Fig. 2 is more informative to characterize the difference.
In the wavelengths where positive maxima were obtained, the wavelengths except $1510 \mathrm{~nm}$ can be assigned to - CONH - of the peptide combination $^{8}$. The $2180 \mathrm{~nm}$ is usually used as a key band for protein analysis with a NIR instrument. The $1510 \mathrm{~nm}$ has been assigned to a first overtone of $-\mathrm{NH}^{9}$, however, there is a possibility of assignment to $-\mathrm{OH}$ of moisture which is strongly bound to protein itself by hydrogen bonding ${ }^{10)}$.

On the other hand, absorbances at the wavelengths where negative minima were obtained decrease in intensity with protein con. tent. There is no wonder that the $2100 \mathrm{~nm}$ is assigned to $-\mathrm{OH}$ of carbohydrates according to a literature ${ }^{11}$. The $1860 \mathrm{~nm}$ has not been assigned, however, this wavelength may also be assigned to a substance related to carbohydrates, judging from the fact that this absorption was observed prominently in the second derivative spectrum of several sugars.

A value of normalized $\Delta \log (1 / R)$ at $2180 \mathrm{~nm}$ is 0.007 as shown in Fig. $2(B)$. As there is

Table 2 Results of calibrations using different data treatments for protein and 4 kinds of amino acids in rice flour

\begin{tabular}{|c|c|c|c|c|c|c|c|c|}
\hline \multirow{2}{*}{ Compositions } & \multirow{2}{*}{ Math used ${ }^{1)}$} & \multicolumn{4}{|c|}{ Wavelengths used (nm) } & \multirow{2}{*}{$\mathrm{R}^{\text {2) }}$} & \multirow{2}{*}{$\begin{array}{c}\mathrm{SEE}^{3)} \\
(\%)\end{array}$} & \multirow{2}{*}{$\begin{array}{l}\left.\mathrm{CV}^{4}\right) \\
(\%)\end{array}$} \\
\hline & & WI & W2 & W3 & W4 & & & \\
\hline \multirow{3}{*}{ Asparatic acid } & $\log (1 / R)$ & 2204 & 2104 & 2174 & - & 0.996 & 0.016 & 2.05 \\
\hline & $\mathrm{d} \log (1 / R)$ & 1668 & 1548 & 2118 & 2338 & 0.999 & 0.008 & 1.03 \\
\hline & $\mathrm{d}^{2} \log (1 / R)$ & 1690 & 2110 & 2086 & 2176 & 0.997 & 0.014 & 1.80 \\
\hline \multirow{3}{*}{ Glycine } & $\log (1 / R)$ & 2204 & 2094 & - & - & 0.989 & 0.010 & 2.63 \\
\hline & $\operatorname{dlog}(1 / R)$ & 1668 & 1550 & 2120 & 1282 & 0.999 & 0.003 & 0.79 \\
\hline & $\mathrm{d}^{2} \log (1 / R)$ & 1690 & 2082 & 1252 & 1984 & 0.999 & 0.004 & 1.05 \\
\hline \multirow{3}{*}{ Alanine } & $\log (1 / R)$ & 2204 & 2108 & - & - & 0.990 & 0.013 & 2.73 \\
\hline & $\mathrm{d} \log (1 / R)$ & 1668 & 1548 & 2027 & 1770 & 0.997 & 0.007 & 1.47 \\
\hline & $\mathrm{d}^{2} \log (1 / R)$ & 1690 & 1774 & 2078 & 2452 & 0.998 & 0.006 & 1.26 \\
\hline \multirow{3}{*}{ Lysine } & $\log (1 / R)$ & 2204 & 2084 & - & - & 0.988 & 0.009 & 3. 09 \\
\hline & $\operatorname{dlog}(1 / R)$ & 1670 & 1550 & 2118 & 1848 & 0.995 & 0.006 & 2.06 \\
\hline & $\mathrm{d}^{2} \log (1 / R)$ & 1690 & 2110 & 1828 & 1570 & 0.999 & 0.003 & 1.03 \\
\hline \multirow{3}{*}{ Protein } & $\log (1 / R)$ & 2202 & 2106 & 2472 & - & 0.992 & 0.226 & 2.62 \\
\hline & $\mathrm{d} \log (1 / R)$ & 1668 & 1298 & 1766 & 2468 & 0.996 & 0.156 & 1.81 \\
\hline & $\mathrm{d}^{2} \log (1 / R)$ & 1688 & 2110 & 2086 & 2056 & 0.990 & 0.267 & 3.10 \\
\hline
\end{tabular}

1) Form of $\log (1 / R)$ used for linear regression analysis, dog $(1 / R)$ : first derivative of $\log (1 / R)$ and $\mathrm{d}^{2} \log (1 / R)$ : second derivative of $\log (1 / R)$

2) Multiple correlation coefficient

3) Standard error of estimation

4) Coefficient of variation 
a difference of $4.5 \%$ in protein content between the samples, the value of $\Delta \log (1 / R)$ per $1 \%$ of the difference in protein content is calculated to be 0.0016 . This is similar to 0.0015 that was calculated from data reported on wheat samples having $8.2 \%$ difference in protein content ${ }^{12)}$. From this point of view, rice protein was verified to be also sensitive to near-infrared as much as wheat protein, and then there is a possibility of the NIR technique to be applied to protein analysis in rice flour.

\section{Calibrations}

Results of calibrations obtained are shown in Table 2. Wavelengths used indicate specific wavelengths at which absorbances were incorporated into independent variables of a stepwise multiple linear regression analysis. The number of wavelengths used is 2 to 4 depending on a kind of calibrations. There are no statistical significance in use of more than 2 or 3 wavelengths in case of calibrations involving the $\log (1 / R)$.

Multiple correlation coefficients of linear regression analysis are more than 0.99 for all the calibrations obtained, and coefficient of variations are in a range of $0.79 \%$ (on lysine with the first derivative of $\log (1 / R) ; \operatorname{dlog}(1 / R))$ to $3.10 \%$ (on protein with the second derivative of $\left.\log (1 / R) ; \mathrm{d}^{2} \log (1 / R)\right)$.

The first wavelengths selected in the multiple linear regression analysis are deperident on the form of absorbances used, but common to calibrations for specific compositions concerned. That is, calibrataions using $\log (1 / R)$, dlog $(1 / R)$ and $\mathrm{d}^{2} \log (1 / R)$ showed $2204,1668 \mathrm{~nm}$ and $1690 \mathrm{~nm}$ as the first wavelength, respectively.

The absorption at $2204 \mathrm{~nm}$ is not clearly observed in the $\log (1 / R)$ spectra (Fig. 1), but is recognized as a shoulder only in the $d^{2} \log$ $(1 / R)$ spectra. Simple correlation coefficients between the $\log (1 / R)$ value at the $2204 \mathrm{~nm}$ and contents of protein and 4 kinds of amino acids are as high as 0.657 with protein, 0.654 with asparatic acid, 0.686 with glycine, 0.659 with alanine and 0.706 with lysine. According to an observation of the $\mathrm{d}^{2} \log (1 / R)$ spectra for substances such as certain proteins and amino acids, the absorption near $2204 \mathrm{~nm}$ appears obviously. In proteins, for example, the intensity of this absorption is dependent on a kind of protein, that is, strong absorption for fibroin but weak for gelatine.

In a previous paper ${ }^{13}$, it was reported that this absorption was recognized as a shoulder in the $d^{2} \log (1 / R)$ spectrum of dried laver and slightly increased in intensity with an increment of moisture content. According to a literature ${ }^{14)}$, this absorption is assumed to be associated with a combination of the fundamental valence and deformation vibration of $\mathrm{N}-\mathrm{H}$ and should be related to a configuration of molecule as affected by the hydrogen bonding.

The absorption at $1668 \mathrm{~nm}$ selected as the first wavelength in case of $\operatorname{dlog}(1 / R)$ math appears as a valley in the spectra of Fig. 1. The absorption at $1690 \mathrm{~nm}$ selected as the first wavelength appears very strongly in the $\mathrm{d}^{2} \log$ $(1 / R)$ spectra of rice flour as well as various food-related substances such as proteins, amino acids or sugars, and this absorption may be assigned to the first overtone of $-\mathrm{CH}$ in methyl group $^{15)}$.

Several wavelengths selected next to the first wavelength are common to the calibrations without regard to the sort of compositions concerned, but in most cases the wavelengths show their own characterisitcs for respective compositions. Williams et al. made a measurement of 14 kinds of amino acids in barley by using the $\operatorname{dlog}(1 / R)$ in the calibration. They reported that $1640 \mathrm{~nm}$ selected as the first wavelength was common to all the calibrations for protein and 9 kinds of amino acids. This wavelength can be assigned to a first overtone of $-\mathrm{NH}$ in amino acid residues or protein ${ }^{16)}$.

It is not possible to give an explanation of an exact meaning of the wavelengths selected next to the first wavelength in the calibrations using the $\mathrm{d}^{2} \log (1 / R)$, but the wavelengths of $2176 \mathrm{~nm}$ selected for asparatic acid, 1774 and $2452 \mathrm{~nm}$ for alanine and also $2110 \mathrm{~nm}$ for lysine appear as strong absorptions in the NIR spectra of the respective amino acids(data not shown).

\section{Predictions}

Results of prediction on 20 "unknown" samples by using the calibrations obtained are shown in Table 3. Standard errors between 
Table 3 Results of prediction for contents of protein and 4 kinds of amino acids by using different calibrations

\begin{tabular}{lccr}
\hline \hline Compositions & Math used & $\operatorname{SEP}^{11}(\%)$ & Bias $(\%)$ \\
\hline \multirow{3}{*}{ Asparatic acid } & $\log (1 / R)$ & 0.027 & -0.009 \\
& $\mathrm{~d} \log (1 / R)$ & 0.032 & -0.021 \\
& $\mathrm{~d}^{2} \log (1 / R)$ & 0.038 & 0.027 \\
Glycine & $\log (1 / R)$ & 0.012 & -0.003 \\
& $\mathrm{~d} \log (1 / R)$ & 0.015 & -0.009 \\
& $\mathrm{~d}^{2} \log (1 / R)$ & 0.016 & 0.008 \\
Alanine & $\log (1 / R)$ & 0.016 & 0.005 \\
& $\mathrm{~d} \log (1 / R)$ & 0.014 & -0.002 \\
Lysine & $\mathrm{d}^{2} \log (1 / R)$ & 0.018 & 0.019 \\
& $\log (1 / R)$ & 0.013 & -0.003 \\
& $\mathrm{~d} \log (1 / R)$ & 0.016 & -0.008 \\
Protein & $\mathrm{d}^{2} \log (1 / R)$ & 0.024 & 0.010 \\
& $\log (1 / R)$ & 0.273 & 0.078 \\
& $\mathrm{~d} \log (1 / R)$ & 0.219 & 0.013 \\
& $\mathrm{~d}^{2} \log (1 / R)$ & 0.303 & 0.251 \\
\hline
\end{tabular}

1) Standard error of prediction

he values of NIR prediction and chemical analysis are larger than those of estimation in the calibrataion, and also bias obtained as a mean difference between both the values becomes larger with an increment of the order of derivative.

As for amino acids, on the other hand, at first they were supposed to be analyzed depedently on the fact that there was a relationship between contents of protein and amino acids in the sample. However, judging from the fact that unique combination of wavelengths was obtained for each amino acid, it is verified that the NIR technique is able to be applied to amino acid analysis in the same sense as reported by Williams et al. ${ }^{16)}$. And RUBENTHALER and BRUINSMA ${ }^{17)}$. In fact, simple correlation coefficients between the contents of protein and amino acids in rice flour used in the present study are as high as 0.990 with asparatic acid, 0.984 with glycine, 0.989 with alanine and 0.975 with lysine, respectively.

In addition, it is suggested to perform a calibration concerning amino acid-protein ratio so that a new variety may be easily discovered in the course of breeding progarmme. That is, a variety with a larger value in the amino acid-protein ratio indicates a possibility of a new variety which has different characteristics from others.

\section{REFERENCES}

1) Iwamoto, M., Cho, R. K., SuzUKi, T. and Uozumi, J. : Nippon Shokuhin Kogyo Gakkaishi, 31, 50 (1984).

2) Starr, C., Morgan, A. G. and Smith, D. B.: J. Agric. Sci., Camb., 97, 107 (1981).

3) Gill, S., Starr, C. and Smith, D. B.: J. Agric. Sci., Camb., 93, 727 (1979).

4) Iwamoto, M., Hirata, T., Suzuki, T., Uozumi, J. and Ishitani, T. : Nippon Shokuhin Kogyo Gakkaishi, 30. 397 (1983).

5) KaffKa, K. J., Norris, K. H. and Rosza-Kiss, M. : Acta Alimentaria, 11, 199 (1982).

6) Yasui, A., Tsutsumi, C., Tatra, H., Araya, S. and Watanabe, O.: Rept. Natl. Food Res. Inst., No. 34, 156 (1979).

7) Suzuki, T., Tamura, S. and Tanaka, Y. : Rept. Natl. Food Res. Inst., No. 31, 24 (1976).

8) Krikorian, S.E. and Mahpour, M.: Spectrochimica Acta, 29 A, 1233 (1973).

9) Hecht, K. T. and Wood, D. L. : Proc. Roy. Soc. (London), 235, 174 (1956). 
10) Ellis, J. W. and BATh, J. D. : J. Chem. Phys. 6, 723 (1938).

11) Miller, R. G. J. and Willis, H. A. : J. Appl. Chem. (London), 6, 385 (1956).

12) Norris, K. H. : "Post-harvest Physiology and Crop Preservation" (Plenum Publishing Corporation), pp. 471-484 (1983).

13) Iwamoto, M., Suzuki, T., Hirata, T., Noda, H., UozUmi, J. and Ishitani, T. : Nippon Shokuhin Kogyo Gakkaishi, 30, 544 (1983).

14) Bath, J. D. and Ellis, J. W. : J. Phys. Chem., 45, 204 (1941).

15) KaYe, W. : Spectrochimica, 6, 257 (1954).

16) Williams, P.C., Preston, K. R. and Strakey, P.M. : Proceeding of the 7 th International Cereals and Bread Congress, Prague, Czechoslovakia, June (1982).

17) Rubenthaler, G. L. and Bruinsma, B. L. : Crop Sci., 18, 1039 (1978).

(Received Oct. 21, 1985)
近赤外分光法による米粉中のたん白及び アミノ酸の測定

岩元㓐夫*·鈴木忠直"ナムチューン コングセリ** 魚住 純* 稲津 倠***

- 農林水産省食品総合研究所 (广305 茨城県筑波 郡谷田部町観音台 2-1-2)

**タイ国農務省米研究所 (タイ国バンコク市バン ケン 10900)

*** 北海道立中央農業試験場( 郡長沼町)

近赤外分光法を用いて米粉中のたん白及び 4 種のアミ ノ酸(フスパラギン酸，グリシン，フラニン、リジン) の測定を行った．同一粉砕条件下では，たん白含量の多 い米粉汪ど粒度が粗く吸光度が大きくなる.近赤外は米 たん白彷し小麦たん白と同程度に感度を有する，微分 スペクトルにより粒子径の差による影響を補借すること が可能である. たん白の測定には十分な精度を有し，そ の実用性が確認されたが，フミノ酸に関しては良好な結 果を得たものの，たん白との関連で間接的な測定である 可能性もある. 1 次锰分より 2 次微分を用いたキャリブ レーションによる未知陚料の測定において，ハイフスが 大きくなる傾向があった。

\section{新刊紹介}

The Lectins

Properties, Functions, and Applications in Biology and Medicine

Liener, I. E., Sharon, N., Goldstein, I. J. 編

“Molecular Biology シリーズ”の一編である.レクチ ンは赤血球を凝集させる特異蛋白質として，マメ科植物 から分䧹されたのが始りであるが，現在では，ガン細胞 の凝集など生化学面からの興味を呼び起こし，遣不子工 学的手法による生産も試みられている，本書は，このレ
クチンについて，植物，動物，貒生物のレクチンについ て, また，その生理学的効果等についてまとめてある， 目次から捨らと，1. 歷史的背景. 2. マメ類のレクチン, 3.レクチンの生化学, 4. レクチンの利用, 5. 植物レク チンの分布と役割， 6. 動物のレクチン，7. 儴生物のレ クチン，8. 食飼中レクチンの栄養学的意義などである.

14. $5 \mathrm{~cm} \times 22.2 \mathrm{~cm} \quad 600$ 頁

72.50 ドル

Academic Press Inc.

Orlando, Florida 32887, U.S. A. 